\title{
Yrjö Sirolan syntymästä 100 vuotta - Suomen vv. 1905-1906 opetuksista
}

Tänä vuonna marraskuun 8. päivänä tulee kuluneeksi 100 vuotta erään Suomen työväenliikkeen merkittävimmän henkilön, Yrjö Sirolan syntymästä. Sirola toimi työväenliikkeen piirissä vuodesta 1904 lähtien, aluksi toimittajana tamperelaisessa Kansan lehdessä, myöhemmin vaihtelevissa tehtävissä $\mathrm{mm}$. vanhan työväenpuolueen puoluesihteerinä suurlakon jälkeisinä voimakkaan etenemisen vuosina sekä ulkoasiainvaltuutettuna kansanvaltuuskunnassa talvella 1918.

Työväenvallankumouksen tappion jälkeen Sirola eli lopun elämänsä maanpakolaisena Neuvostoliitossa, missä hän toimi monissa tehtävissä, elämänsä loppuaikoina mm. Leninkoulun professorina. 1920/30-luvulla hän toimi ennen kaikkea pedagogina, mutta kirjoitti tällöinkin jatkuvasti artikkeleita SKP:n maanalaiseen lehdistöön sekä Neuvostoliitossa ilmestyneisiin suomenkielisiin julkaisuihin.

Sirola on jättänyt jälkeensä laajan kokoelman lehtiartikkeleita sekä muuta kirjallista aineistoa. Julkaisemme tässä numerossa lyhennelmän Sirolan artikkelista Suomen vv. 1905 -1906 opetuksista. Artikkeli on alunperin julkaistu vuoden 1935 Kommunistissa. Artikkelissa ilmenee vuosien 1905-06 tärkeä merkitys Suomen työväenliikkeen kehitykselle. Sen tutkiminen ei ole mikään muodollisuus, vaan osa elävää perinnettä, joka on toimintavoimamme tänäkin päivänä.

Suomen kansalla oli juuri näinä vuosina erikoinen syy tarkistaa taistelutapansa tsarismia vastaan. V. 1899 oli Nikolai II n.s. helmikuun julistuskirjalla suorittanut valtiokaappauksen, julistanut mitättömäksi Suomen autonomian, sille varsin rajoitettunakin arvokkaan itsehallinnon, ja kenraalikuvernööri Bobrikovin diktatuurivallan kautta toteutti venäläistyttämisohjelmaa. (Ks. Leninin artikkelia v:lta 1903 kirjassa "Kansallisuuskysymys"). Tärkeimpänä pyrkimyksenä tsarismilla oli hävittää Suomen oma sotaväki ja viedä suomalaiset palve- lemaan eri osiin laajaa keisarikuntaa, samalla moninkertaisesti lisâten militarismin taakkaa. Voidakseen tämän suorittaa oli - tsarismin murskattava se vastarinta, mitä suomalaisten puolelta näitä toimenpiteitä vastaan tehtiin. Jo ennenkin hyvin ahtaalle aidatut kansalaisvapaudet riistettiin, : tehtiä lakkautettiin, kansa-

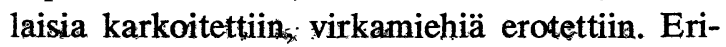
kọisesti kuristettiin työväenliikettä. Lakkoja ei kylläkään . ihan avoimetla väkivạlalla lyöty alas, mutta Suomen kapitalistit saivat tsaarin sotaväeltä apua polkiessaan työväen taisteluita. Työväenlehtiä pidettiin ankaran sensuurin alaisena. Uusien työväenyhdistyksien perustamista vaikeutettiin ja niiden toimintaa valvottiin tiukasti. V. 1903 puolueohjelman periaatteellinen osa, Itävallan sdp:n ohjelmasta suomennettu, otettiin takavarikkoon; se puoluekokouskin pidettiin tarkan poliisivalvonnan alaisena. Se että puolue näissä oloissa ei täydentänyt julkista toimintaansa järjestelmällisellä salaisella toiminnalla ja organisatiolla, oli vakava virhe. Oli kyllä sellaista yhteydenpitoa, mitä ei viranomaisille näytetty, mutta se perustui pelkkiin persoonallisiin yhteyksiin. Näinä aikoina muodostui kyllä salaisia järjestöjäkin. Ne auttoivat venäläisiä vallankumoukselsisia yhteyden pidossa yms. Osa niistä oli yhteydessä porvarillisten aktivistien, Venäjän eser-puolueen liittolaisten, kanssa, osaksi niiden johdonkin alaisena. Mutta juuri se, että tällä toiminnalla ei ollut kiinteää ohjelmaa eikä marxilaista johtoa, oli suorastaan kohtalokasta.

Perustuslaillisten vastarinta oli varsin heikkoa. Kun sen ainoana ohjelmankohtana oli muodollisesta laillisuudesta kiinnipitäminen, mikä suureksi osaksi merkitsi etuoikeutettujen säätyjen erikoisaseman puolustamista sekä tsaaria että Suomen kansan suurta enemmistöä vastaan, niin ei sellainen voinut olla tehoisaa - ainakaan tsarismiin päin. Niinpä havaitaankin, että perustuslailliset alkoivat yhä 
onemmän taipua tsarismin vaatimusten edessä. Mutta työväen ja talonpoikain vaatimuksiin nähden olivat ne lujia. Keskellä sortoaikaa, v. 1902, hyväksyttiin säädyissä uusi maavuokralaki, joka jopa huononsi epävapaitten talonpoikain, torpparien ja mäkitupalaisten asemaa. Perustuslailliset kapitalistit ja kartanonherrat, jotka kyllä vaativat itselleen kansalaisvapauksia, kielsivät ne alustalaisiltaan. Ja kun heidän työläisensä tekivät lakkoja, niin olivat nämä "isänmaalliset" valmiit kutsumaan venäläistä sotaväkeä avuksi. Niin tapahtui Hyvinkäällä v. 1902 ja Voikkaalla v. 1904. Ymmärtäen, että tällainen ei voi olla porvarilliseltakaan kannalta edullista, alkoi osa sivistyneistöä ym. pikkuporvarillisia aineksia etsiä jyrkempiä menettelytapoja. Perustettiin "Aktiivisen vastarinnan puolue", jonka johtaja oli Konni Zilliacus. Tämä puolue pani toimeen terroristisia tekoja, v. 1904 surmattiin Bobrikov, sitten suomettarelainen prokuraattori Soisalo-Soininen; joitakin hallitusmiehiä, kuvernöörejä ja santarmipäälliköitä vastaan tehtiin murhayrityksiä. Puolue hommasi myös aseita (aselaiva "John Grafton") ja järjesti salaisia ryhmiä, joihin kuului työläisiäkin, sosdem puolueen jäseniä. Osa aktivisteista tunnustautui myös jonkinlaisiksi "sosialisteiksi".

Sosdem puolue tunnusti tietenkin periaatteessa vastarinnan tsarismin kuristustoimenpiteitä vastaan ja arvosteli porvarillista vastarinnan liikettä sen heikkouden takia. Erikoisesti korosti puolue työväen kansalaisvapauksien ja -oikeuksien vaatimusta. Työväenliikkeen järjestöt ja toimitsijat olivat tehokkaimpana voimana vastarintatoimenpiteissä (asevelvollisuuslakoissa, mielenosoituksissa). Puolue ei kuitenkaan järjestänyt tuntuvampia taistelu-otteita, vaikka väliin syntyikin yhteenottoja poliisivallan ja mielenosoittajain kesken.

Suomessa kyllä ymmärrettiin, että tsaarillisia sortotoimenpiteitä ei suomalaisilla voimilla kyetä ehkäisemään; siksi odotettiinkin har- taasti Venäjän vallankumousta ja ihailtiin venäläisiä vallankumouksellisia. Mutta näitä ei lähestytty. Ei edes murrettu sitä vakavaa estettä, jonka kielentaitamattomuus asetti. Suomessa oli vuosisata käyty taistelua ruotsinkielen ylivaltaa vastaan eikä sitäkään vielä oltu murrettu. Venäjänkieltä suorastaan boikoteerattiin. Työväenliikkeessä oli aniharvoja, jotka kykenivät suomentamaan venäläisistä lehdistä ja keskustelemaan venäläisten kanssa. Mitä yhteyttä oli, se tapahtui etupäässä saksankielen välityksellä. Helsingissä oli kyllä venäläisiä tovereita, jotka osasivat ruotsia. Niinpä bolsheviikki, yliopiston lehtori V. Smirnov kirjoitteli säännöllisesti Leninin "Iskraan" Suomen kirjeitä. Hänen v. 1933 ilmestynyt kirjansa "Suomen vallankumouksellisesta historiasta 1905, 1917, 1918" sisältää arvokkaita tietoja bolshevikkien yhteydestä suomalaisten sosialidemokraattien ja aktivistien kanssa.

Vaikka siis Venäjän vallankumousta odotettiinkin, tulivat vallankumoustapahtumat kuitenkin yllätyksenä. Ei oltu niiiden varalta suunniteltu menettelytapoja. Tsarismin tappio Venäjän-Japanin sodassa alkoi jo 1904 tuntua vissinä helpotuksena. Työväenkin toimintavapaudet laajenivat. Ja sitä mukaa kuin Venäjän vallankumousliike v. 1905 kohosi," rohkaistuivat Suomessakin työväenjoukot. Mielenosoituksia pidettiin yhä taajemmin, vaadittiin sortotoimenpiteitten lopettamista ja yleistä äänioikeutta. Kun Suomen sääđyt huhtik. 14-15 p. hylkäsivăt edes kahden säädyn kansanvaltaistuttamisen, niin alettiin työväenkokouksissa esittää uutta tunnusta: että 'oli saatava yleisillä vaaleilla valittu perustava kansalliskokous uudistamaan Suomen valtiojärjestystä. Leninin tunnusta "työväen ja-talonpoikain vallankumouksellis-demokraattinen diktatuuri" ei tunnettu.

Kun sitten lokakuussa Venäjällä puhkesi suurlakko, levisi se pian Suomeenkin. Lokakuun 30 p:nä se alkoi Helsingissä, Kotkassa, Viipurissa, Tampereella ym. leviten nopeasti 
yli maan. Työväki sen alkoi ja olivat johdossa paikalliset puolueosastot. Kun puoluejohto ei ennättänyt antamaan yhtenäisiä ohjeita, olivat vaatimukset ja menettelytavat jossain määrin erilaiset. Toisin paikoin olivat työväenjärjestöt hyvinkin läheisessä yhteydessä porvarillisten perustuslaillisten kanssa. Kun näet porvarilliset huomasivat kansanliikkeen valtavuuden, riensivät ne liittymään mukaan. Lakossa olivat myös koulut ja virastot. Porvaristo nimitti lakon "kansallislakoksi' ja olivatkin siinä etualalla kansalliset vaatimukset: laittomien sortotoimenpiteiden peruuttaminen ja kansalaisvapauksien esteetön käyttö. Nyt täytyi porvariston myöskin hyväksyä yleisen äänioikeuden vaatimus sekä myös luvata yksikamarinen eduskunta. Mutta taistelutavat olivat proletaariset.

Työväen yleisimmäksi ohjelmaksi tuli Tampereella hyväksytty, Yrjö Mäkelinin kirjoittama "Punainen julistus", joka hyväksyttiin tilanteessa, jolloin oli yleisenä huhu, että tsaari oli kukistettu. Siinä julistuksessa vaadittiin räikein sanoin tsarismin kätyrien viroista poisajamista ja kansalliskokouksen kokoonkutsumista. Sitä kutsumaan ja asioita hoitamaan oli asetettava väliaikainen hallitus, jonka Helsingin kansa valitsee. Tampereella, jossa allekirjoittanut oli silloin suurlakkokomitean sihteerinä, oli näin rohkean kannan otto suhteellisen helppo. Eihän kaupungissa ollut sotaväkeä: santarmit vangittiin ja venäläinen poliisimestari livisti tiehensä.

Helsingissä, johon Y. Mäkelinin johtama delegatio vei Punaisen julistuksen, oli asema hieman mutkikkaampi. Siellä oli venäläinen garnisoni ja kenraalikuvernööri, joka kyllä oli luvannut erota, mutta yhä oli toimessa. On säilynyt santarmiraportti, jonka mukaan kenraalikuvernööri tiedusteli sotaväen päälliköltä, kykenisivätkö nämä ottamaan työväen punakaartilta poliisikamarin ja pitämään hallussaan kaupungin, mutta oli saanut kieltävän vastauksen. Työväen keskuudessa levisi huhuja, että sotaväki on luvannut olla ampumatta kansaa, mutta sitäkään ei käytännössä koeteltu. Tilanne kävi erikoisen jännittäväksi, kun rautatien torilla marraskuun 4 p. suoritettiin "väliaikaisen hallituksen" vaali kädennostoäänestyksellä. Että ei ollut kysymystä todellisesta vallankumouksellisesta taisteluhallituksesta, se käy jo selville siitä, että listalle oli otettu koko joukko porvarispuolueitten toimitsijain nimiä, meidän sosialidemokraattien lisäksi. Näiltä ei oltu siihen suostumusta kysytty. Ja kun kenraalikuvernööri, joka oli siirtynyt panssarilaiva "Slavalle", selitti, että hän pitää tällaista tekoa sodan julistuksena tsaaria ja Venäjää vastaan, varsinkin kun jo on tullut tsaarin manifesti Suomen kansalle, niin peräytyi suurlakon johto ja punakaartin päällikön, kapteeni Johan Kockin, seiniin naulatulla tiedonannolla selitettiin, että vaali alistetaan - hallitsijan, s.o. tsaarin vahvistettavaksi! Näin oli vallankumoukselta katkaistu kärki ja marrask. 6 p. julistettiin lakko päättyneeksi.

Suurlakkoviikolta voisi paljonkin kertoa. Pitkin maata nousivat pohjajoukot ja valitsivat vallankumouksellisia elimiä, suurlakkokomiteoita, joiden käsiin joutui valta paikkakunnilla. Järjestystä pitämään asetettiin 'kansalliskaarteja". Helsingissä kuului sellaiseen ensin työläisiä ja ylioppilaita, mutta pian alkoi työväki nimittää joukkojaan punakaarteiksi korostaen sillä niiden kumouksellista luonnetta. Taisteluhalu oli joukoissa ilmeinen ja oltiin valmiit vaatimusten puolesta avoimeenkin taisteluun, niin huonosti kun siihen olikin valmistauduttu. Lakon loppupäivinä jo seisottiin aseet käsissä ylioppilaiden "lahtarikaartia" vastaan.

Lenin pani mitä suurimman huomion Moskovan aseelliseen kapinaan jouluk. 1905, pitäen sitä tämän, tappioon päättyneen vallankumouksen, huippukohtana. Juuri sellaiset 
taistelut muodostivat tärkeän osan sitä "pääharjoitusta", joka edisti v:n 1917 suurta voittoa. Suomessa ei tällaista pääharjoitusta saatu. Tilanne oli kyllä hyvin jännittävä noina samaisina joulukuun päivinä, ja Helsingissä pidettiin silloin koko maata käsittävä edustajakokous, jossa pohdittiin suurlakkokysymystä. Samalla pidettiin valtava mielenosoitus, "viimeinen varoitus" säädyille, että eivät viivyttelisi marraskuun lupausten täyttämistä. Kovin nopeasti ei se kuitenkaan käynyt. Vasta toukokuussa hyväksyttiin uusi Valtiopäiväjärjestys, jonka mukaan yksikamarisen eduskunnan vaaleissa on miehillä ja naisilla yleinen ja yhtäläinen äänioikeus. Ikärajan asettivat säädyt 24 vuodeksi sekä tekivät lakiin joukon muitakin epädemokraattisia pykäliä. Niiden päätös perustui kuitenkin pääasiassa tsaari-suuriruhtinaan antamaan "armolliseen" esitykseen. Syksymmällä tsaari sitten tämän lain vahvisti, ja vaikka hän sitten useita kertoja eduskunnan hajoittikin, ei hän kuitenkaan yleiseen äänioikeuteen kajonnut.

Suurimmaksi voitoksi $1905-06$ vallankumoustaisteluista tuli se valtava herätys, joka silloin kulki yli maan. Poliittinen harrastus tempasi mukaansa pohjimmaisetkin raatajajoukot. Kokouksia pidettiin, vaatimuksia esitettiin, työväenyhdistyksiä ja ammattiliittoja perustettiin, sanomalehtiä ja kirjallisuutta julkaistiin. Työväentaloja rakennettiin, niin että niitä tuli olemaan toista vertaa enemmän kuin kirkkoja. Niistä muodostui paikkakunnan työtätekevien joukkojen poliittisia ja kulttuurikeskuksia. Tämän liikkeen laajuudesta antaa todistuksen sekin, että v. 1907 toimitetuissa ensimmäisissä vaaleissa sosdem puolue sai 80 edustajaa, 40 pros. eduskunnan jäsenistä.

Laaja lakkoliike nousi myös koko maassa, vaikka puolue koettikin sitä pidätellä, selittäen, että on säästettävä voimat suureen poliittiseen ponnistukseen, jos eduskuntauudistusta ei ala kuulua. Allekirjoittanut, joka sil- loin oli puoluesihteerinä - puoluejohto oli muutettu Helsinkiin - kantaa osaltaan tästä vastuun. Kuitenkin on huomautettava, että joukot eivät näistä varotteluista paljoakaan välittäneet. Kun ammatillinen järjestäytyminen ei käynyt yhtä jalkaa joukkojen taisteluhalun kanssa, oli suuria vaikeuksia lakkolaisten avustamisessa, ja päätyivätkin useat lakot tappioon. Vasta 1907 saatiin perustetuksi Ammattijärjestö, joka pian paisui aika voimakkaaksi. Kaikkinainen muukin työväen alotteellisuus sai vallankumoustapahtumista voimakkaan sysäyksen. Urheilu-, näytelmä-, raittius-, valistus- ym. järjestöjä kasvoi kuin sieniä sateella.

Vallankumouksellisen taistelun tulosta oli vielä se, että Suomen työväenliikkeessä eivät oikeistolaiset ainekset päässeet täydelleen johtoon. Puolueen vasemmisto, "siltasaarelaiset", joutui kyllä yhteistoiminnassa oikeistolaisten kanssa samassa puolueessa maksamaan raskaan veron sopuilun kautta ja olemmekin sitä seuraavaa aikaa nimittäneet reformistisen rämettymisen ajaksi. Kuitenkin on $1905-06$ perinteiden vaikutukseksi suurelta osalta luettava se, että Suomen sosdem puolue ei v. 1918 porvariston taantumuksellisen hyökkäyksen edessä antautunut, vaan otti vastaan taisteluhaasteen. Edellä mainittujen puutteiden ja virheiden syytä on taas se, että tässä taistelussa ei saatu voittoa, kuten sitä asiaa lukuisissa yhteyksissä on selvitetty.

Suomen kansalle muodostui v. 1905-06 aivan ratkaisevaksi käännekohdaksi. Työtätekevät valloittivat silloin itselleen "kansalaisoikeudet", astuivat poliittiselle näyttämölle. Siitä ne eivät sitten ole väistyneetkään, vaikka suurporvaristo onkin useita kertoja niitä väkivallalla "pariain" asemaan koettanut painaa. Meidän kommunistien on pidettävä huolta siitä, että näiden taistelujen kunniakkaat muistot eivät pääsisi unhoon häipymään eikä niiden kalliisti ostetut opetukset menemään hukkaan. 